\title{
ARTICLE
}

Cite this: DOI: $10.1039 / \times 0 \times x 00000 x$

\section{Structure and Properties of $\mathrm{MgM}_{\mathrm{x}} \mathrm{Cr}_{2-\mathrm{x}} \mathrm{O}_{4}(\mathrm{M}=\mathrm{Li}$, $\mathrm{Mg}, \mathrm{Ti}, \mathrm{Fe}, \mathrm{Cu}, \mathrm{Ga})$ spinels for electrode supports in Solid Oxide Fuel Cells}

Received 00th January 2012, Accepted 00th January 2012

DOI: $10.1039 / \times 0 \times x 00000 x$

www.rsc.org/

\author{
Elena Stefan $^{a}$, Paul A. Connor ${ }^{a}$ Abul K. Azad ${ }^{a, \#}$ and John T. S. Irvine ${ }^{a, *}$
}

Novel electrode scaffold materials based on chromium-rich spinels, such as $\mathrm{MgM}_{\mathrm{x}} \mathrm{Cr}_{2-\mathrm{x}} \mathrm{O}_{4}$, $(\mathrm{M}=\mathrm{Li}, \mathrm{Mg}, \mathrm{Ti}, \mathrm{Fe}, \mathrm{Cu}, \mathrm{Ga}$ ) have been investigated for Solid Oxide Fuel Cell (SOFC) applications, in terms of conductivity and chemical stability when operated in fuel environments. Cation distributions were obtained by Rieveld refinement from X-ray diffraction data (XRD), with cation site preference considered in agreement with literature, and correlated with electrical properties determined experimentally. The substitutions with cations such as $\mathrm{Li}$ and $\mathrm{Cu}$ on $\mathrm{B}$ site improved the conductivity of the materials in air, while introducing $\mathrm{Fe}$ and $\mathrm{Ga}$ in the structure led to a decrease in conductivity in air. However, $\mathrm{Fe}$ had a positive contribution under reducing conditions, generating a change in the conductivity mechanism from p-type in air, to n-type. Conductivity measurements indicated that $\mathrm{MgFe}_{\mathrm{x}} \mathrm{Cr}_{2-\mathrm{x}} \mathrm{O}_{4}$ spinels exhibit faster reduction kinetics, in comparison with other substituted cations at the $\mathrm{B}$ site which is desirable in fuel cell application, for a reasonably fast response of a cell or a stack to reach its full functional potential. $\mathrm{MgFeCrO}_{4}$ showed fast reduction kinetics, with increase of the conductivity in reducing conditions from $0.014 \mathrm{~S} \mathrm{~cm}^{-1}$ to $0.4 \mathrm{~S} \mathrm{~cm}^{-1}$ and equilibration time for reaching the maximum conductivity value of 10 hours, under dry $5 \% \mathrm{H}_{2} / \mathrm{Ar}$ at $850{ }^{\circ} \mathrm{C}$.

\section{Introduction}

The limited availability of fossil energy sources and the increase of the total greenhouse emissions in the last century reinforced the concept of renewable energy usage and the development of appropriate technologies, such as fuel cells. ${ }^{1}$ Solid Oxide Fuel Cells (SOFCs) are high efficiency electrochemical devices which convert chemical energy into electrical energy directly from the oxidation of fuels. ${ }^{2,3}$ SOFCs consists of two porous electrodes separated by a dense, ion (typically oxide) conducting but electronically insulating electrolyte. At the cathode, $\mathrm{O}_{2}$ is reduced to $\mathrm{O}^{2-}$ which travels through the electrolyte to the anode and oxidise the fuel, releasing electrons into the outer circuit and thus generating power. ${ }^{4}$ For good performance and durability, the materials used for the electrodes should meet several requirements, including, but not limited to, chemical and structural stability during the preparation and operation, similar thermal expansion coefficients, adequate porosity, ionic and electronic conductivity and catalytic activity. ${ }^{5-7}$

These requirements cannot be easily fulfilled by one material alone, especially in the case of the anode, which needs both ionic and electronic conduction, such as obtained in the composite Ni-yttria stabilised zirconia (YSZ) cermet. This particular electrode shows good performance but suffers degradation in certain conditions, due to low redox tolerance. ${ }^{8}$ To overcome these problems several anode formulations and architectures are being investigated. The most promising and versatile approach so far seems to be the use of a porous scaffold with either good ionic (e.g. YSZ) or electronic (e.g. perovskites) conductivity in which various species are added (infiltrated) to fulfil the electrochemical/catalytic functions which the scaffold is lacking. ${ }^{9-20}$

Cr-rich spinels are good potential anode support materials because these are similar to the main corrosion product of ferritic stainless steel and thus are expected to be more 
compatible with metallic interconnect interfaces as compared to other oxide systems.

Spinel oxides are characterised by the general formula $\mathrm{AB}_{2} \mathrm{O}_{4}$ with $\mathrm{A}$ being a tetrahedral cation and $\mathrm{B}$, an octahedral cation and display a cubic crystal structure with a symmetry described by the space group $F d \overline{3} m$ (No. 227). ${ }^{21}$ One unit cell contains 8 $\mathrm{AB}_{2} \mathrm{O}_{4}$ spinel formula units, which is a total of 56 atoms (with $8 \mathrm{~A}$ cations, $16 \mathrm{~B}$ cations and 32 oxygen anions). Oxygen anions form a cubic closed packed lattice with 64 tetrahedral and 32 octahedral sites partially filled with cations. The occupancy for the tetrahedral sites is only $1 / 8$ and for the octahedral sites is $1 / 2$. The similar size for the $\mathrm{A}$ and $\mathrm{B}$ cations makes it possible that cations which support both coordination numbers can interchange sites, thus leading to the so called inverse spinels. Inversion can be synthetically expressed as $\left(\mathrm{A}_{1-\gamma} \mathrm{B}_{\gamma}\right)_{T d}\left(\mathrm{~A}_{\gamma} \mathrm{B}_{2-\gamma}\right)_{O h} \mathrm{O}_{4}$, where subscripts $T d$ and $O h$ refer to the tetrahedral and octahedral sites, respectively. Normal spinels are formed for $\mathrm{x}=0$, perfectly inverse spinels for $\mathrm{x}=1$, while intermediate values for $\gamma, 0<\gamma<1$, are called randomly inverse spinels. ${ }^{21,22}$

The cation distribution amongst tetrahedral and octahedral sites is governed by the minimization of the total energy with respect to several factors, including the field stabilization energy (CFSE) of cations, the charge and the size of the cations. ${ }^{23-25}$ Cations with noble gas electron configurations have no preference for either coordination and their distribution is determined mainly by the size and energy of the lattice (e.g. $\left.\mathrm{Li}^{+}, \mathrm{Mg}^{2+}, \mathrm{Al}^{3+}, \mathrm{Ti}^{4+}\right)$. Cations with half-filled $3 \mathrm{~d}$ shells have spherical-like charge distribution (e.g. $\mathrm{Mn}^{2+}, \mathrm{Fe}^{3+}$ ), therefore without expected preference for either position, while those with $3 \mathrm{~d}^{3}$ an $3 \mathrm{~d}^{8}$ (e.g. $\mathrm{Cr}^{3+}, \mathrm{Ni}^{2+}, \mathrm{Mn}^{4+}$ ) have strong preference for six-fold coordination because of the high corresponding crystal field stabilisation energy (Figure 1). The site preference of cations with various degrees of d-orbital occupancy $\left(\mathrm{d}^{1}, \mathrm{~d}^{2}\right.$, $\mathrm{d}^{4}, \mathrm{~d}^{6}, \mathrm{~d}^{7}$ and $\left.\mathrm{d}^{9}\right)$ can be estimated in an initial, simplified approach based on the relative magnitude of their corresponding CFSE, calculated according to references 26,27 and plotted in Figure 1.

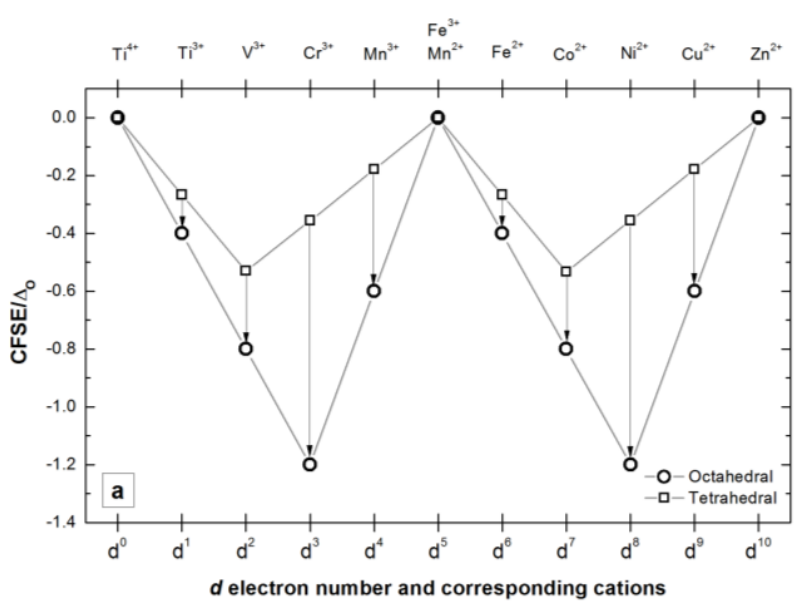

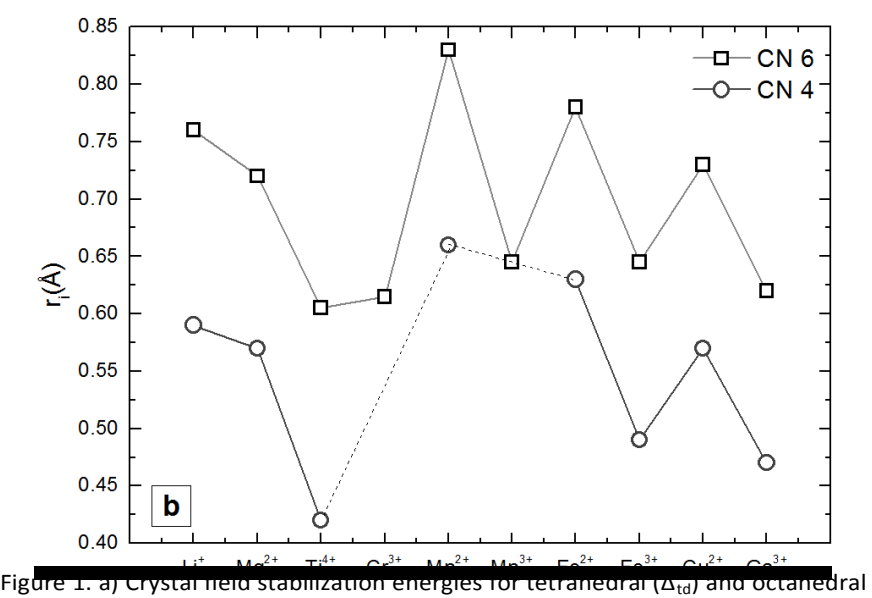

coordination $\left(\Delta_{o c t}\right)$, for cations with different number of $d$ electrons. Calculated according to ref ${ }^{26,27} . \Delta_{0}$ represents the magnitude of the split of the d orbitals; b) lonic radius ${ }^{28}$ for $\mathrm{Mn}^{2+}, \mathrm{Fe}^{2+}, \mathrm{Li}^{+}, \mathrm{Cu}^{2+}, \mathrm{Mg}^{2+}, \mathrm{Mn}^{3+}, \mathrm{Fe}^{3+}$ and $\mathrm{Ga}^{3+}$ and coordination numbers (CN). Dashed lines illustrate the absence of ionic radii of $\mathrm{Cr}^{3+}$ and $\mathrm{Mn}^{3+}$ for $\mathrm{CN}=4$. Solid lines indicate the variation of ionic radii for cations used in this study with $\mathrm{CN}=4$ and $\mathrm{CN}=6$.

Spinels are typically p-type semiconductors. Electronic conduction occurs by thermally activated hopping of electron holes throughout the $\mathrm{B}$-sites because the $\mathrm{BO}_{6}$ octahedra share edges and thus the B-B distances are relatively short $(\sim 0.35 \mathrm{a}$, Figure $2 \mathrm{~b}){ }^{22}$ For example in chromium spinels conduction is described by hopping of an electron hole $\mathrm{h}+$ between chromium ions with different valences: ${ }^{29}$

$$
C r_{C r}^{\times}+h \leftrightarrow C r_{C r}^{.}
$$

Equation 1

The reduction reaction leads to a decrease in the number of charge carrier sources $\left(\mathrm{Cr}^{4+}\right.$ ions), equivalent with a decrease in the hole concentration, according to the equilibrium:

$$
\mathrm{O}_{O}^{\prime \prime}+2 \mathrm{Cr}_{\mathrm{Cr}}^{\cdot} \leftrightarrow 2 \mathrm{Cr} r_{C r}^{\times}+V_{O}^{*}+1 / 2 \mathrm{O}_{2} \text { Equation } 2
$$

As a consequence of the reduction, for charge balance there must also be the formation of vacancies in the oxygen sublattice $\mathrm{V}_{\mathrm{O}}$ of the spinel.

However, spinels are typically known to only be able to incorporate a small concentration of vacancies and thus oxygen vacancies would not be expected to dominate spinel defect chemistry, but it would be possible that spinels incorporate more or less oxygen per formula unit through cation vacancies or interstitials e.g. $\mathrm{M}_{3 \pm \delta} \mathrm{O}_{4}{ }^{30}$ In the specific case of chromite and ferro-chromites mostly discussed here, it would be expected that a small amount of cation vacancies form at high oxygen pressure during material processing (Moriwake et al. ${ }^{31-}$ ${ }^{33}$ ).

In order to increase conductivity in reducing conditions (since spinels are lacking in this respect), possibly associated with a change in the conductivity mechanism from p-type to n-type semiconductor upon reduction, chromium ions have been partially substituted with isovalent or aliovalent cations.

Previously, $\mathrm{MnCr}_{2} \mathrm{O}_{4}, \quad \mathrm{MnM}_{\mathrm{x}} \mathrm{Cr}_{2-\mathrm{x}} \mathrm{O}_{4}$ and $\mathrm{MgCr}_{2} \mathrm{O}_{4}$ were investigated $^{34}$ for assigning the chemical stability of such spinels in reducing conditions. Here, the cation substitutions properties relationship, and in particular chemical stability and electrical conductivity, of newly formulated $\mathrm{Cr}$-rich spinels, such as $\mathrm{MgM}_{\mathrm{x}} \mathrm{Cr}_{2-\mathrm{x}} \mathrm{O}_{4}(\mathrm{M}=\mathrm{Li}, \mathrm{Mg}, \mathrm{Ti}, \mathrm{Fe}, \mathrm{Cu}, \mathrm{Ga})$ has been studied for porous electrode support materials. Selected spinels were shown to carry out the anode support role successfully. ${ }^{35,36}$ 


\section{ARTICLE}
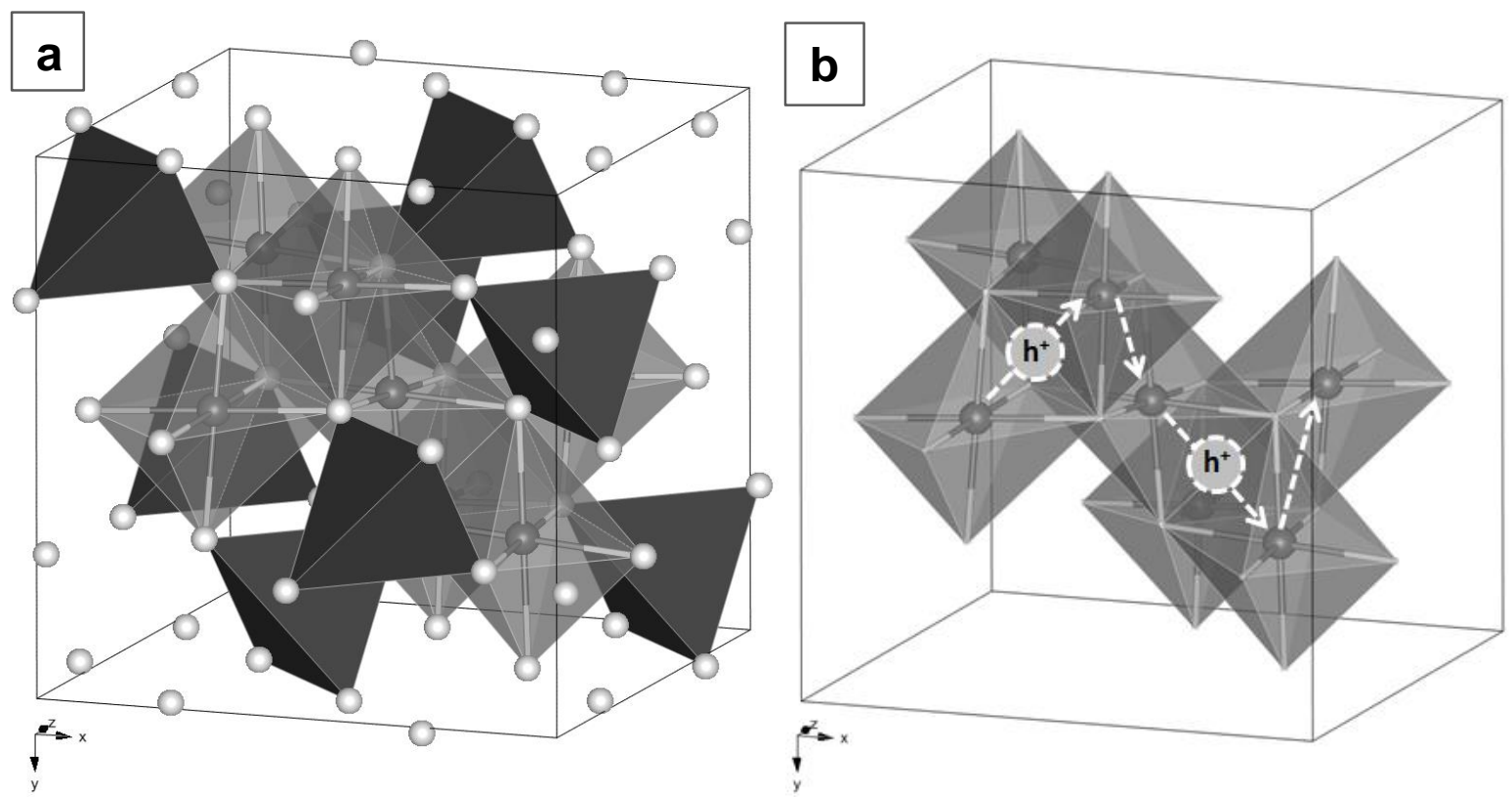

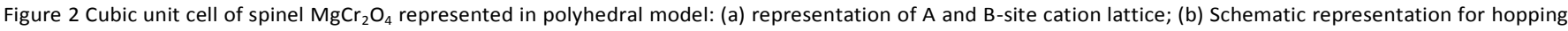
of an electron hole in the B-site cation lattice (in order to simplify the representation, the A site lattice was omitted).

\section{Experimental}

Samples containing $\mathrm{Li}, \mathrm{Mg}, \mathrm{Fe}$ and $\mathrm{Cu}$ were prepared by citric acid - nitrate combustion synthesis, ${ }^{34}$ while the samples containing $\mathrm{Ti}, \mathrm{Ga}$ were prepared by solid state reaction. After the combustion reaction was complete, the obtained powders were calcined at $1000{ }^{\circ} \mathrm{C}$ for 10 hours. For solid state synthesis $\mathrm{Cr}_{2} \mathrm{O}_{3}$ (Alfa Aesar (99\%)), $\left(\mathrm{MgCO}_{3}\right)_{4} \mathrm{Mg}(\mathrm{OH})_{2} \cdot 5 \mathrm{H}_{2} \mathrm{O}$ (Aldrich (99\%)), $\mathrm{TiO}_{2}$ (Alfa Aesar (99.5\%)), $\mathrm{Ga}_{2} \mathrm{O}_{3}$ (Aldrich (99.99\%)) were weighed in stoichiometric amounts and mixed using an ultrasonic probe in acetone for 10 minutes, in order to obtain a good dispersion of the oxides and homogenisation. A small amount of dispersant KD1 (1 wt \%) was added and the dispersion was stirred for 2 hours. The mixtures were dried and the resulting powders were calcined at $1000{ }^{\circ} \mathrm{C}$ for 10 hours. After being calcined, the powders were milled for 2 hours in acetone and then dried. The resulting powders were then pressed into pellets (13 $\mathrm{mm}$ diameter and $2 \pm 0.3 \mathrm{~mm}$ thickness) at a pressure of $\sim 200 \mathrm{MPa}$ and sintered at $1400{ }^{\circ} \mathrm{C}$ for 12 hours in air.

XRD patterns were initially collected for preliminary phase purity analysis on either a Philips PW 1710 X-ray diffractometer operated in reflection mode, or on a PANalytical Empyrean Diffractometer also operated in reflection mode, to serve for advanced structural analysis. The high resolution XRD patterns were analysed via the Rietveld method by using the Fullprof software ${ }^{37}$ in order to extract information regarding unit cell parameters (a, $\AA$ ), oxygen coordinate parameters (u, $\AA$ ), as well as cation distribution among tetrahedral and octahedral sites. Initial cation distributions were assumed based on typical cation site preference, as reported in the literature. $^{21,23,31,38,39}$ The inversion was refined only at later stages of the refinement, after the background, scale factor, cell parameter, oxygen parameter, peak profile parameters and the thermal factor were refined. In the case of species with very similar X-ray scattering factors such as $\mathrm{Fe}, \mathrm{Cr}$ and $\mathrm{Mn}$, the inversion degree was not refined because XRD cannot accurately discriminate between them and, as such, they were considered to be normal spinels.

D.C. electrical conductivity measurements were performed in static air or in reducing atmosphere of a continuous gas flow of $50 \mathrm{~cm}^{3} / \mathrm{min} 5 \% \mathrm{H}_{2} / \mathrm{Ar}$. Four Pt foils of $\sim 1 \mathrm{~mm}$ thickness were applied parallel onto a pellet surface, as shown in Figure 3, with platinum paste and sintered at $900{ }^{\circ} \mathrm{C}$ for a good contact between the platinum contacts and the pellet. Relative densities of measured pellets were $55-70 \%$ dense, while the sample $\mathrm{MnFeCrO}_{4}$ had a relative density of $80 \%$. The experimental setup is described in ref ${ }^{40}$.

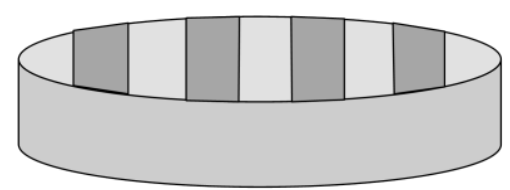

Figure 3. Contact geometry used for 4-terminal conductivity measurements. 


\section{Results and discussion}

\subsection{Phase analysis and crystal structure}

Spinel oxides $\mathrm{MgM}_{\mathrm{x}} \mathrm{Cr}_{2-\mathrm{x}} \mathrm{O}_{4},(\mathrm{M}=\mathrm{Li}, \mathrm{Mg}, \mathrm{Ti}, \mathrm{Fe}, \mathrm{Cu}, \mathrm{Ga})$ were synthesised by solution combustion synthesis or by solid state reaction as described in the experimental section and were investigated with respect to phase analysis, density, chemical stability in reducing conditions and electrical conductivity.

Compositions such as $\mathrm{MgGa}_{\mathrm{x}} \mathrm{Cr}_{2-\mathrm{x}} \mathrm{O}_{4} \quad(\mathrm{x}=0.1,0.2)$, $\mathrm{MgFe}_{\mathrm{x}} \mathrm{Cr}_{2-\mathrm{x}} \mathrm{O}_{4} \quad(\mathrm{x}=0.1,0.5,1), \quad \mathrm{MgLi}_{\mathrm{x}} \mathrm{Cr}_{2-\mathrm{x}} \mathrm{O} 4 \quad(\mathrm{x}=0.1)$, $\mathrm{MgCu}_{\mathrm{x}} \mathrm{Cr}_{2-\mathrm{x}} \mathrm{O}_{4}(\mathrm{x}=0.1)$ and $\mathrm{Mg}_{1.5} \mathrm{Ti}_{0.5} \mathrm{CrO}_{4}$, were found to form single phase cubic spinels when prepared in air, whereas $\mathrm{MgTi}_{\mathrm{x}} \mathrm{Cr}_{2-\mathrm{x}} \mathrm{O}_{4}(\mathrm{x}=0.1)$ only formed a single phase when prepared in reducing conditions. For $\mathrm{x}=0.2, \mathrm{MgLi}_{\mathrm{x}} \mathrm{Cr}_{2-\mathrm{x}} \mathrm{O}_{4}$, $\mathrm{MgCu}_{\mathrm{x}} \mathrm{Cr}_{2-\mathrm{x}} \mathrm{O}_{4}$ obtained in air and $\mathrm{MgTi}_{\mathrm{x}} \mathrm{Cr}_{2-\mathrm{x}} \mathrm{O}_{4}$, obtained in reducing conditions showed segregation of secondary phases.

The cation distributions, along with $a$, $u$ values and $R_{p}, R_{w p}$, $\mathrm{R}_{\text {exp }}$ and $\chi^{2}$, determined from Rietveld refinement are presented in Table 1. Rietveld refinement was performed in the space group $F d \overline{3} m$ with origin at $\overline{3} m$ and the $\mathrm{A}, \mathrm{B}$, and $\mathrm{O}$ site positions corresponding to $8 \mathrm{a}(1 / 4,1 / 4,1 / 4), 16 \mathrm{~d}(1 / 2,1 / 2,1 / 2)$ and $32 \mathrm{e}$ $(\mathrm{u}, \mathrm{u}, \mathrm{u})$, respectively. Selected refinement plots are illustrated in Figure 4, where observed intensities are plotted with light grey dots, calculated intensities with black line and the difference between calculated and observed intensities is given as dark grey line. XRD was performed on some samples with $\mathrm{Si}$ as internal standard for more accurate cell parameters. The cation distributions obtained from Rietveld refinement are in a good agreement with the CFSE stabilisation energies of the cations (Figure 1 a).

A higher degree of inversion resulted for $\mathrm{MgFe}_{\mathrm{x}} \mathrm{Cr}_{2-\mathrm{x}} \mathrm{O}_{4}$ compositions, between the $\mathrm{Mg}$ and $\mathrm{Fe}$ cations, which could be both the result of non-preference for sites of the $\mathrm{Fe}^{3+}$ cations or the preference for both octahedral and tetrahedral sites of the $\mathrm{Fe}^{2+}$ cations. Also $\mathrm{Cu}$ and $\mathrm{Ga}$ substituted spinels showed small inversions. In case of $\mathrm{MgCu}_{0.1} \mathrm{Cr}_{1.9} \mathrm{O}_{4}$, unexpectedly, the inversion between $\mathrm{Mg}$ and $\mathrm{Cu}$ cations could be the result of no preference for sites of the $\mathrm{Mg}^{2+}$. The size of the two cations should not influence the site preference, since they have almost the same ionic radii at the $\mathrm{A}$ and $\mathrm{B}$ sites (Shannon radii - Figure $1 \mathrm{~b}$ ). In case of $\mathrm{MgGa}_{\mathrm{x}} \mathrm{Cr}_{2-\mathrm{x}} \mathrm{O}_{4}$, the inversion between $\mathrm{Mg}^{2+}$ and $\mathrm{Ga}^{3+}$ was about the same for $\mathrm{x}=0.1$ and $\mathrm{x}=0.2 \mathrm{Ga}$ substituted at the $\mathrm{B}$ site (Table 1). Both, $\mathrm{Ga}^{3+}\left(\mathrm{d}^{10}\right)$ and $\mathrm{Mg}^{2+}$ have no preference for sites, and the ionic radii of the $\mathrm{Ga}^{3+}$ for $\mathrm{CN}=4$ and $\mathrm{CN}=6$ are smaller than for $\mathrm{Mg}^{2+}$, which would determine a certain degree of inversion. However, the octahedral cation radius of $\mathrm{Ga}^{3+}$, is very close to $\mathrm{Cr}^{3+}$ and much smaller than $\mathrm{Mg}^{2+}$, which limits the inversion between $\mathrm{Mg}$ and $\mathrm{Ga}$. Data listed in Table 1, such as unit cell parameters and cation distributions are correlated with conductivity values in section 3.3 .

Table 1 Cation distribution, a, $\mathrm{u}$ and reliability factors for the Rietveld refinement.

\begin{tabular}{|c|c|c|c|c|c|c|c|c|c|}
\hline \multirow[t]{2}{*}{ Composition } & \multicolumn{2}{|c|}{ Cation Distribution } & \multirow[t]{2}{*}{$\gamma( \pm 0.003)$} & \multirow[t]{2}{*}{$\mathrm{a}(\AA)$} & \multirow[t]{2}{*}{$\mathrm{u}(\AA)$} & \multirow[t]{2}{*}{$\mathrm{R}_{\mathrm{p}}(\%)$} & \multirow[t]{2}{*}{$\mathrm{R}_{\mathrm{wp}}(\%)$} & \multirow[t]{2}{*}{$\mathrm{R}_{\exp }(\%)$} & \multirow[t]{2}{*}{$\chi^{2}$} \\
\hline & $(\mathrm{Td})$ & $(\mathrm{Oh})$ & & & & & & & \\
\hline $\mathrm{MgCr}_{2} \mathrm{O}_{4}$ & $(\mathrm{Mg})$ & $\left(\mathrm{Cr}_{2}\right)$ & 0 & $8.33508(5)$ & $0.2613(1)$ & 3.31 & 4.46 & 3.40 & 1.72 \\
\hline $\mathrm{MgGa}_{0.1} \mathrm{Cr}_{1.9} \mathrm{O}_{4}$ & $\left(\mathrm{Mg}_{0.93} \mathrm{Ga}_{0.07}\right)$ & $\left(\mathrm{Ga}_{0.03} \mathrm{Mg}_{0.07} \mathrm{Cr}_{1.9}\right)$ & 0.07 & $8.3330(1)$ & $0.2604(2)$ & 3.30 & 4.52 & 3.26 & 1.93 \\
\hline $\mathrm{MgGa}_{0.2} \mathrm{Cr}_{1.8} \mathrm{O}_{4}$ & $\left(\mathrm{Mg}_{0.92} \mathrm{Ga}_{0.08}\right)$ & $\left(\mathrm{Ga}_{0.12} \mathrm{Mg}_{0.08} \mathrm{Cr}_{1.8}\right)$ & 0.08 & $8.3317(1)$ & $0.2599(2)$ & 3.41 & 4.80 & 3.28 & 2.14 \\
\hline $\mathrm{MgFe}_{0.1} \mathrm{Cr}_{1.9} \mathrm{O}_{4}$ & $\left(\mathrm{Mg}_{0.98} \mathrm{Fe}^{3+}{ }_{0.02}\right)$ & $\left(\mathrm{Mg}_{0.02} \mathrm{Fe}^{3+}{ }_{0.08} \mathrm{Cr}_{1.9}\right)$ & 0.02 & $8.33814(5)$ & $0.2604(2)$ & 3.60 & 5.00 & 3.50 & 2.04 \\
\hline $\mathrm{MgFe}_{0.5} \mathrm{Cr}_{1.5} \mathrm{O}_{4}$ & $\left(\mathrm{Mg}_{0.85} \mathrm{Fe}^{3+}{ }_{0.15}\right)$ & $\left(\mathrm{Mg}_{0.15} \mathrm{Fe}^{3+}{ }_{0.35} \mathrm{Cr}_{1.5}\right)$ & 0.15 & $8.3566(1)$ & $0.2605(2)$ & 2.56 & 3.47 & 2.94 & 1.40 \\
\hline $\mathrm{MgFeCrO}_{4}$ & $\left(\mathrm{Mg}_{0.6} \mathrm{Fe}^{3+}{ }_{0.4}\right)$ & $\left(\mathrm{Mg}_{0.4} \mathrm{Fe}^{3+}{ }_{0.6} \mathrm{Cr}\right)$ & 0.4 & $8.3670(2)$ & $0.2586(2)$ & 1.85 & 2.46 & 2.25 & 1.19 \\
\hline $\mathrm{MgCu}_{0.1} \mathrm{Cr}_{1.9} \mathrm{O}_{4}$ & $\left(\mathrm{Mg}_{0.94} \mathrm{Cu}_{0.06}\right)$ & $\left(\mathrm{Mg}_{0.06} \mathrm{Cu}_{0.04} \mathrm{Cr}_{1.9}\right)$ & 0.06 & $8.3341(2)$ & $0.2625(2)$ & 3.91 & 5.55 & 3.74 & 2.20 \\
\hline $\mathrm{MgLi}_{0.1} \mathrm{Cr}_{1.9} \mathrm{O}_{4}$ & $(\mathrm{Mg})$ & $\left(\mathrm{Li}_{0.1} \mathrm{Cr}_{1.9}\right)$ & 0 & $8.33448(2)$ & $0.2617(2)$ & 3.49 & 5.12 & 3.63 & 1.99 \\
\hline $\mathrm{Mg}_{1.5} \mathrm{Ti}_{0.5} \mathrm{CrO}_{4}$ & $(\mathrm{Mg})$ & $\left(\mathrm{Ti}_{0.5} \mathrm{Mg}_{0.5} \mathrm{Cr}\right)$ & 0.5 & $8.38704(5)$ & $0.2606(1)$ & 4.50 & 6.40 & 4.14 & 2.40 \\
\hline$* \mathrm{MgMnCrO}_{4}$ & $\left(\mathrm{Mg}_{0.8} \mathrm{Mn}^{2+}{ }_{0.2}\right)$ & $\left(\mathrm{Mg}_{0.2} \mathrm{Mn}^{3+}{ }_{0.8} \mathrm{Cr}\right)$ & 0.2 & $8.38080(8)$ & $0.2620(2)$ & 2.63 & 3.65 & 2.85 & 1.64 \\
\hline$* \mathrm{MnCr}_{2} \mathrm{O}_{4}$ & $(\mathrm{Mn})$ & $\left(\mathrm{Cr}_{2}\right)$ & 0 & $8.43757(1)$ & $0.2646(2)$ & 2.46 & 3.34 & 2.96 & 1.27 \\
\hline$* \mathrm{MnFe}_{0.1} \mathrm{Cr}_{1.9} \mathrm{O}_{4}$ & (Mn) & $\left(\mathrm{Fe}_{0.1} \mathrm{Cr}_{1.9}\right)$ & 0 & $8.44210(2)$ & $0.2636(2)$ & 2.73 & 4.10 & 2.98 & 1.89 \\
\hline$* \mathrm{MnFeCrO}_{4}$ & $(\mathrm{Mn})$ & $(\mathrm{FeCr})$ & 0 & $8.46714(3)$ & $0.2640(3)$ & 2.12 & 3.09 & 2.34 & 1.75 \\
\hline$* \mathrm{MnLi}_{0.1} \mathrm{Cr}_{1.9} \mathrm{O}_{4}$ & $\left(\mathrm{Mn}^{2+}{ }_{0.98} \mathrm{Li}_{0.02}\right)$ & $\left(\mathrm{Mn}^{3+}{ }_{0.02} \mathrm{Li}_{0.08} \mathrm{Cr}_{1.9}\right)$ & 0.02 & $8.43203(2)$ & $0.2657(3)$ & 2.64 & 4.03 & 2.89 & 1.94 \\
\hline
\end{tabular}

(*) Spinels studied in our previous work

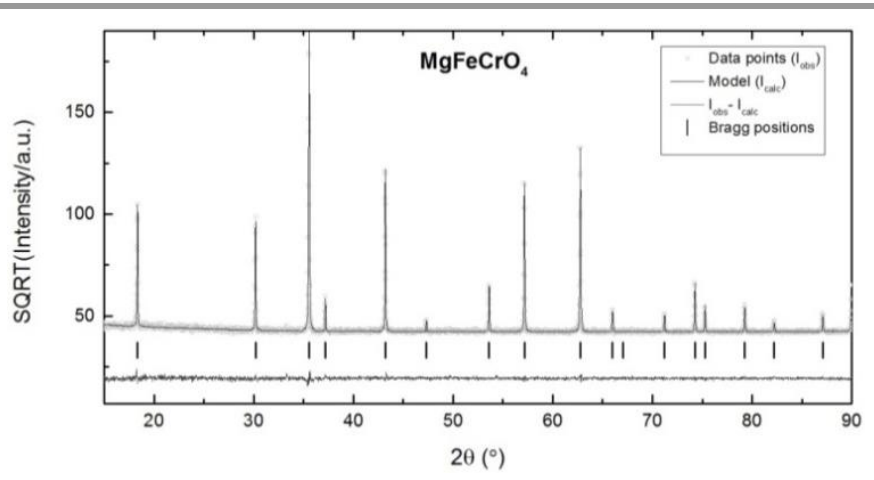

4 | J. Name., 2012, 00, 1-3

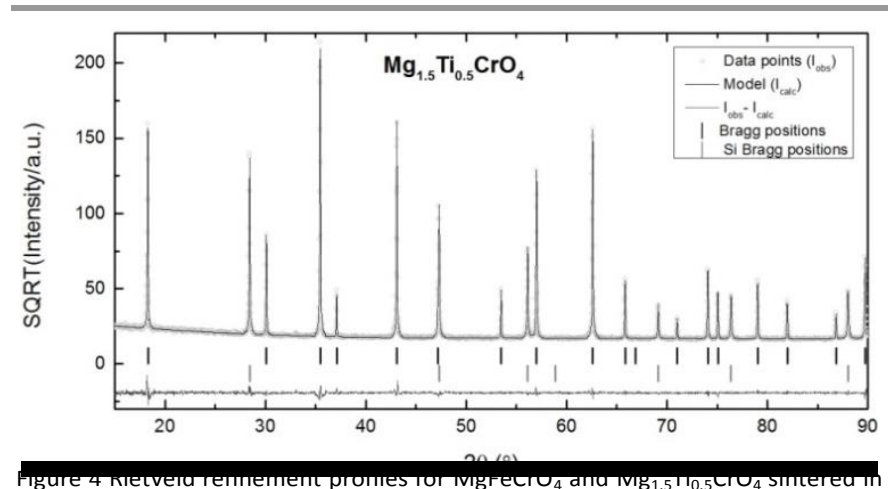

air at $1400^{\circ} \mathrm{C}$ for $12 \mathrm{~h}$. Observed data is represented with light grey dots, calculated profile with black line and difference profile with dark grey line, note Si internal standard in $\mathrm{Mg}_{1.5} \mathrm{Ti}_{0.5} \mathrm{CrO}_{4}$. 


\subsection{Chemical stability in reducing conditions}

The anode of an SOFC is exposed to both highly reducing fuels and high steam conditions, thus the use of spinels as anode support materials in SOFCs requires chemical stability of the materials in such conditions. The chemical stability in reducing conditions was determined by applying thermal treatments in $5 \% \mathrm{H}_{2} / \mathrm{Ar}$ at $1000{ }^{\circ} \mathrm{C}$ for 20 hours. In the $\mathrm{MgM}_{\mathrm{x}} \mathrm{Cr}_{2-\mathrm{x}} \mathrm{O}_{4}$ series, samples with $\mathrm{M}=\mathrm{Ga}(\mathrm{x}=0.1,0.2)$, $\mathrm{Ti}(\mathrm{x}=0.1)$ and $\mathrm{Cu}$ $(\mathrm{x}=0.1)$ no phase change was found upon reduction, while samples with $\mathrm{M}=\mathrm{Fe}(\mathrm{x}=0.1,0.5,1)$ showed segregation of metallic $\mathrm{Fe}$ and $\mathrm{MgO}$. The segregation of $\mathrm{Fe}$ and $\mathrm{MgO}$ for $\mathrm{MgFeCrO}_{4-\delta}$ is reported in $\mathrm{ref}^{35}$ in its application as electrode support. $\mathrm{MgFeCrO}_{4-\delta}$ was stable when reduced at $850{ }^{\circ} \mathrm{C}$ for 30 hours in $5 \% \mathrm{H}_{2} / \mathrm{Ar}$ with no evidence of Fe (Figure 5), which indicates its stability in fuel environments when operated lower than $850{ }^{\circ} \mathrm{C}$. When reduced in humidified $\left(3 \% \mathrm{H}_{2} \mathrm{O}\right) 5 \% \mathrm{H}_{2} / \mathrm{Ar}$ at $1000{ }^{\circ} \mathrm{C}$ for 20 hours, $\mathrm{MgFeCrO}_{4}$ was also stable. ${ }^{35}$ The $\mathrm{XRD}$ patterns are included in Figure 5.

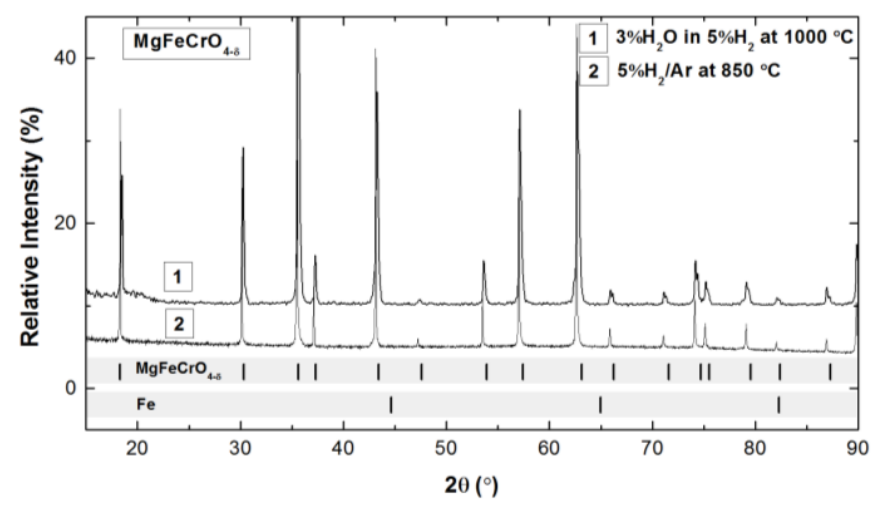

Figure $5 \mathrm{X}$-ray diffraction pattern of $\mathrm{MgFeCrO}_{4-\delta}$ reduced in dry $5 \% \mathrm{H}_{2} / \mathrm{Ar}$ at $850{ }^{\circ} \mathrm{C}$ for $30 \mathrm{~h}$ and in humidified $5 \% \mathrm{H}_{2} / \mathrm{Ar}$ at $1000^{\circ} \mathrm{C}$ for 20 hours (XRD pattern 1 was collected on a Philips PW 1710 X-ray diffractometer, showing $\mathrm{K} \alpha 1$ and $\mathrm{K} \alpha 2$ lines in the XRD pattern).

\subsection{Electrical properties}

Electrical conductivity measurements were conducted both in air and reducing conditions $\left(5 \% \mathrm{H}_{2} / \mathrm{Ar}\right)$ on porous ceramic bodies prepared by sintering in air at $1400{ }^{\circ} \mathrm{C}$ corresponding to $\mathrm{MgM}_{\mathrm{x}} \mathrm{Cr}_{2-\mathrm{x}} \mathrm{O}_{4}(\mathrm{M}=\mathrm{Li}, \mathrm{Mg}, \mathrm{Ti}, \mathrm{Fe}, \mathrm{Cu}, \mathrm{Ga})$ and $\mathrm{MnM}_{\mathrm{x}} \mathrm{Cr}_{2-\mathrm{x}} \mathrm{O}_{4}$. The materials preserved the p-type semiconducting behaviour upon substitutions by all cations in air and reducing conditions, except for $\mathrm{Ti}$ and higher $\mathrm{Fe}$ content which induced an increase in conductivity when reduced (n-type behaviour). Figure 6 a illustrates the Arrhenius plot of selected spinels and in Figure 7 the effect of $\mathrm{Li}, \mathrm{Mg}, \mathrm{Ti}, \mathrm{Fe}, \mathrm{Cu}, \mathrm{Ga}$ substitutions at the $\mathrm{B}$ site can be compared in terms of conductivity reached in air and reducing conditions.

The activation energy $\left(E_{a}, e V\right)$ of the conductivity measured in air was estimated for two temperature domains: low temperature range $\left(100-450{ }^{\circ} \mathrm{C}\right)$ and high temperature range $\left(450-850{ }^{\circ} \mathrm{C}\right)$. The $\mathrm{E}_{\mathrm{a}}$ values are plotted vs. the cell parameter for $\mathrm{MgM}_{\mathrm{x}} \mathrm{Cr}_{2-\mathrm{x}} \mathrm{O}_{4}$ and $\mathrm{MnM}_{\mathrm{x}} \mathrm{Cr}_{2-\mathrm{x}} \mathrm{O}_{4}$ (Figure 6 and Table 1.). $\mathrm{E}_{\mathrm{a}}$ decreased with increasing temperature for $\mathrm{MgM}_{\mathrm{x}} \mathrm{Cr}_{2-\mathrm{x}} \mathrm{O}_{4}$, which is characteristic for a ceramic going from grain boundary to bulk domination of the resistance, while for $\mathrm{MnM}_{\mathrm{x}} \mathrm{Cr}_{2-\mathrm{x}} \mathrm{O}_{4}, \mathrm{E}_{\mathrm{a}}$ increased with the temperature. ${ }^{34} \mathrm{~A}$ similar phenomenon was observed for $\mathrm{MgFe}_{\mathrm{x}} \mathrm{Cr}_{2-\mathrm{x}} \mathrm{O}_{4}$ series, possibly indicating a decrease in number of charge carriers associated with a disorder of the cations at the $\mathrm{B}$ site. The spinels for which the substitution at the B site and the inversion degree are higher, showed a decrease in conductivity and higher $\mathrm{E}_{\mathrm{a}}$ values. While for substitutions of $\mathrm{Li}$ and $\mathrm{Cu}$ on the $\mathrm{A}$ site, the $\mathrm{B}$ lattice remained mainly based on $\mathrm{Cr}^{3+}$ cations, the conductivity increased and $\mathrm{E}_{\mathrm{a}}$ values decreased, as would be expected if they induced a higher concentration of charge carrier at the $\mathrm{B}$ sites. Figure $6 \mathrm{~b}$ shows an increase of the $E_{a}$ values with the cell parameter for a bigger cation at the A site, such as $\mathrm{Mn}$ in comparison with $\mathrm{Mg}$. A larger cation occupying the A site increases the distance between the B site cations and decreases the overlapping of the $d$ orbitals, thus increasing the energy necessary for the hoping of electron holes. The exceptions from the linear trend for each spinel series are both connected to the substitution of $\mathrm{Cr}$ with $\mathrm{Fe}$ on the $\mathrm{B}$ site.

The conductivity measured in air for $\mathrm{MgFe}_{\mathrm{x}} \mathrm{Cr}_{2-\mathrm{x}} \mathrm{O}_{4}$ series $(\mathrm{x}=0,0.1,0.5,1)$ decreased with increasing iron content. A minimum value of $2 \times 10^{-3} \mathrm{~S} \mathrm{~cm}^{-1}$ at $850{ }^{\circ} \mathrm{C}$ corresponded to $\mathrm{x}=0.5$, and for $\mathrm{x}=1$ conductivity increased again to $0.014 \mathrm{~S} \mathrm{~cm}^{-1}$. In reducing conditions, the conductivity increased with the iron content, as shown in Figure 7 a, where the maximum value corresponded to $\mathrm{x}=1$, with $0.4 \mathrm{~S} \mathrm{~cm}^{-1}$.

The influence of $\mathrm{Ga}$ doping on the electrical conductivity was negative, with $\mathrm{MgGa}_{\mathrm{x}} \mathrm{Cr}_{2-\mathrm{x}} \mathrm{O}_{4}(\mathrm{x}=0.1,0.2)$ showing lower conductivity than $\mathrm{MgCr}_{2} \mathrm{O}_{4}$ in both air and reducing atmosphere, as illustrated in Figure 7 a. Thus, the investigation of spinels with higher content of $\mathrm{Ga}$ substituted at the $\mathrm{B}$ site was not investigated. The conductivity measured in air and reducing conditions, for $\mathrm{MgM}_{0.1} \mathrm{Cr}_{1.9} \mathrm{O}_{4}$ series $(\mathrm{M}=\mathrm{Ga}, \mathrm{Li}, \mathrm{Cu}$, $\mathrm{Fe}$ ) demonstrated an increase in conductivity for $\mathrm{Li}$ and $\mathrm{Cu}$ substitutions, as observed in Figure $7 \mathrm{~b} \mathrm{MgFe}_{\mathrm{x}} \mathrm{Cr}_{2-\mathrm{x}} \mathrm{O}_{4-\delta}$ and $\mathrm{MnFe}_{\mathrm{x}} \mathrm{Cr}_{2-\mathrm{x}} \mathrm{O}_{4-\delta}$ series showed an increase in conductivity when reduced. The increase in conductivity could indicate the formation of $\mathrm{Fe}^{2+} / \mathrm{Fe}^{3+}$ couples, increasing the total number of charge carriers. $\mathrm{MgFe}_{0.1} \mathrm{Cr}_{1.9} \mathrm{O}_{4-\delta}$ maintained its p-type conductivity behaviour when reduced. But for higher $\mathrm{Fe}$ content, the conductivity changed, with $\mathrm{MgFe}_{0.5} \mathrm{Cr}_{1.5} \mathrm{O}_{4-\delta}$ and $\mathrm{MgFeCrO}_{4-\delta}$ showing n-type conductivity on reduction.

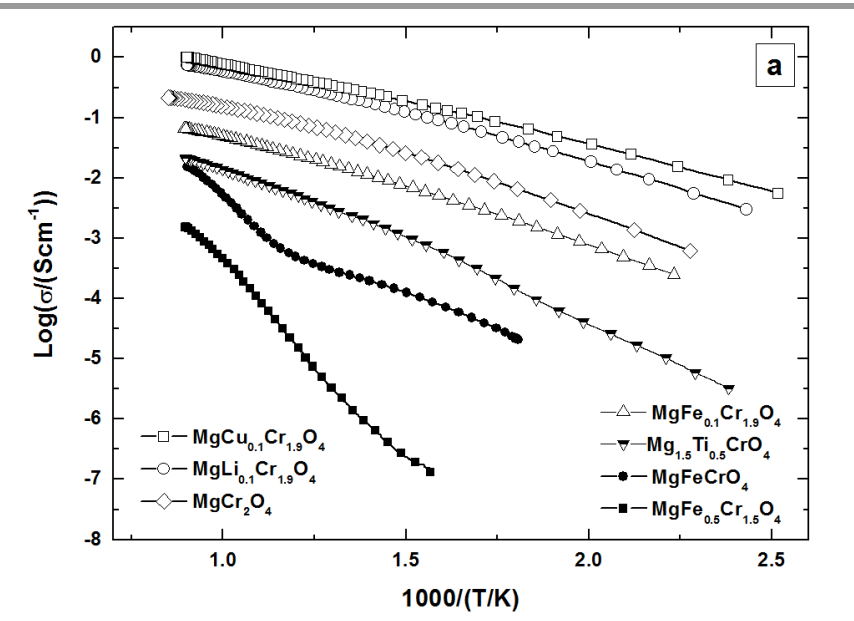




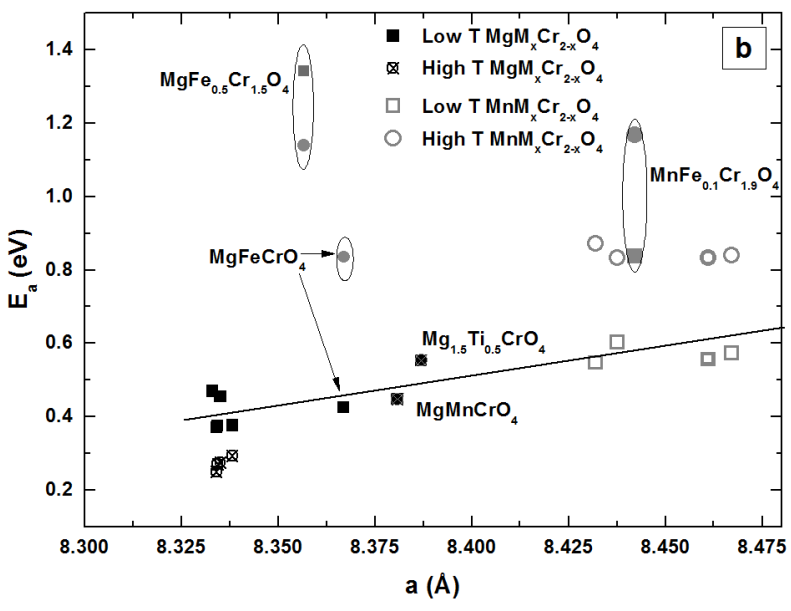

Figure 6 a) Arrhenius plots for listed spinels determined from DC electrical measurements in air for temperature range $100-870^{\circ} \mathrm{C}$; b) Activation energy dependence with unit cell parameter and temperature in air for listed materials; the marked positions correspond to $\mathrm{MgFe}_{0.5} \mathrm{Cr}_{1.5} \mathrm{O}_{4}$ (full circle), $\mathrm{MgFeCrO}_{4}$ (full square/circle) and $\mathrm{MnFe}_{0.1} \mathrm{Cr}_{1.9} \mathrm{O}_{4}$ (full square/circle).

Electrical properties for $\mathrm{MnM}_{\mathrm{x}} \mathrm{Cr}_{2-\mathrm{x}} \mathrm{O}_{4}$ spinels have been measured only in air because most of these samples segregate secondary phases in reducing conditions. The influence of substitution on $\mathrm{B}$ site with $\mathrm{Li}, \mathrm{x}=0.1$ had similar influence to the one observed for $\mathrm{MgLi}_{0.1} \mathrm{Cr}_{1.9} \mathrm{O}_{4}$ but here the increase in conductivity was more consistent. Introducing a small amount of $\mathrm{Fe}$ on $\mathrm{B}$ site led to a minimum value of conductivity and the increase of $\mathrm{Fe}$ content increased the conductivity of the material, similar to $\mathrm{MgFe}_{\mathrm{x}} \mathrm{Cr}_{2-\mathrm{x}} \mathrm{O}_{4}$ series. The plotted points represent conductivity values after the apparent equilibration of the samples in air or reducing conditions, at $850^{\circ} \mathrm{C}$.

The response of the material in terms of conductivity, upon the sudden change in $\mathrm{pO}_{2}$ is plotted against time, as illustrated in Figure 8, for $\mathrm{MgLi}_{0.1} \mathrm{Cr}_{1.9} \mathrm{O}_{4-\delta}, \quad \mathrm{MgCu}_{0.1} \mathrm{Cr}_{1.9} \mathrm{O}_{4-\delta}$, $\mathrm{MgFe}_{0.1} \mathrm{Cr}_{1.9} \mathrm{O}_{4-\delta}, \quad \mathrm{MgFe}_{0.5} \mathrm{Cr}_{1.5} \mathrm{O}_{4-\delta}, \quad \mathrm{MgFeCrO}_{4-\delta} \quad$ and $\mathrm{Mg}_{1.5} \mathrm{Ti}_{0.5} \mathrm{CrO}_{4-\delta}$. The $p \mathrm{O}_{2}$ value decreased within a matter of minutes to $\sim 10^{-18}$ atm and was kept constant for the duration of the experiments assured by a continuous gas flow of $50 \mathrm{~cm}^{3} / \mathrm{min} 5 \% \mathrm{H}_{2} / \mathrm{Ar}$. The plots show a fast initial decrease in conductivity for $\mathrm{MgLi}_{0.1} \mathrm{Cr}_{1.9} \mathrm{O}_{4-\delta}, \quad \mathrm{MgCu}_{0.1} \mathrm{Cr}_{1.9} \mathrm{O}_{4-\delta}$ and $\mathrm{MgFe}_{0.1} \mathrm{Cr}_{1.9} \mathrm{O}_{4-\delta}$, followed by a continuous and slower decrease in conductivity for $\mathrm{MgLi}_{0.1} \mathrm{Cr}_{1.9} \mathrm{O}_{4-\delta}, \mathrm{MgCu}_{0.1} \mathrm{Cr}_{1.9} \mathrm{O}_{4-\delta}$, while the conductivity of $\mathrm{MgFe}_{0.1} \mathrm{Cr}_{1.9} \mathrm{O}_{4-\delta}$ reached a plateau region, after approximately 15 hours.

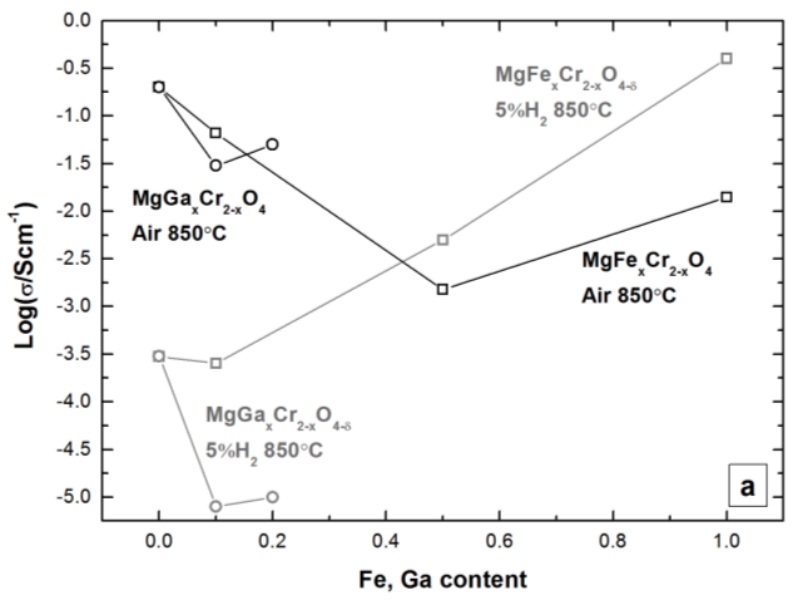

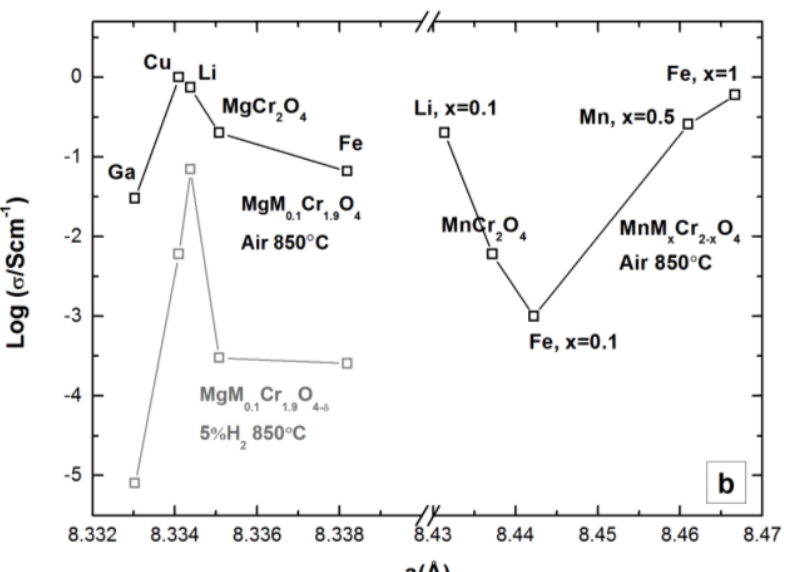

Figure 7 a) Log $(\sigma)$ vs. the Fe content for ${ }^{\prime \Lambda} \mathrm{MgFe}_{x} \mathrm{Cr}_{2-\mathrm{x}} \mathrm{O}_{4}$ equilibrated in air and reducing conditions at $850{ }^{\circ} \mathrm{C}$ and $\mathrm{Log}(\sigma)$ vs. the $\mathrm{Ga}$ content for $\mathrm{MgGa}_{x} \mathrm{Cr}_{2-x} \mathrm{O}_{4}$ in air and reducing conditions at $850^{\circ} \mathrm{C}$; b) Log $(\sigma)$ vs. the cell parameter for $\mathrm{MgM}_{0.1} \mathrm{Cr}_{1.9} \mathrm{O}_{4}$ in air and reducing conditions at $850^{\circ} \mathrm{C}$ and $\log (\sigma)$ vs. the cell parameter for $\mathrm{MnM}_{\mathrm{x}} \mathrm{Cr}_{2-\mathrm{x}} \mathrm{O}_{4}$ in air and reducing conditions at $850{ }^{\circ} \mathrm{C}$.

Upon reduction, $\mathrm{MgFe}_{0.5} \mathrm{Cr}_{1.5} \mathrm{O}_{4-\delta}$ and $\mathrm{MgFeCrO}_{4-\delta}$ showed a fast increase in conductivity within the first hour, of 1 order of magnitude, from 0.014 to $\sim 0.4 \mathrm{~S} \mathrm{~cm}^{-1}$ for $\mathrm{MgFeCrO}_{4-\delta}$ and only $\sim 0.3$ order of magnitude, from 0.0013 to $\sim 0.003 \mathrm{~S} \mathrm{~cm}^{-1}$ for $\mathrm{MgFe}_{0.5} \mathrm{Cr}_{1.5} \mathrm{O}_{4-\delta}$.

$\mathrm{Mg}_{1.5} \mathrm{Ti}_{0.5} \mathrm{CrO}_{4-\delta}$ shows an initial decrease of 2 orders of magnitude in the conductivity, within the first hour of reduction. Following this, its conductivity increased slowly, showing n-type conductivity.

$\mathrm{MgFe}_{0.1} \mathrm{Cr}_{1.9} \mathrm{O}_{4-\delta}, \mathrm{MgFe}_{0.5} \mathrm{Cr}_{1.5} \mathrm{O}_{4-\delta}$ and $\mathrm{MgFeCrO}_{4-\delta}$ reached a conductivity plateau in the reduction time allocated in each case, while $\mathrm{MgLi}_{0.1} \mathrm{Cr}_{1.9} \mathrm{O}_{4-\delta}, \quad \mathrm{MgCu}_{0.1} \mathrm{Cr}_{1.9} \mathrm{O}_{4-\delta}$ and $\mathrm{Mg}_{1.5} \mathrm{Ti}_{0.5} \mathrm{CrO}_{4-\delta}$ did not reach a plateau in the observed reduction time. The data were fitted to a decay function, in order to indicate the minimum time required for equilibrating the conductivity of the samples at $850{ }^{\circ} \mathrm{C}$ and $\mathrm{pO}_{2} \sim 10^{-18}$ atm. Neagu and Irvine ${ }^{2}$ used a similar mathematical model for fitting a kinetically controlled mass loss during titanate perovskite reduction. They described the characteristics of the reduction as being controlled by two (first order) processes: a fast process corresponding to the reduction of the surface and a slow process corresponding to the diffusion of the oxygen from the bulk towards the surface of the material. The datasets are described by equation 3 , for which the two exponentials reflect the kinetics of two processes, as follows:

$$
(\sigma)(t)=s_{0}+s_{1} \cdot e^{-k_{2}\left(t-t_{0}\right)}+s_{3} \cdot e^{-k_{4}\left(t-t_{0}\right)} \text { Equation } 3
$$

The equation implies two diffusion processes are occurring: process 1 , described by $s_{1}$ and $\mathrm{k}_{2}$ constants and process 2 with constants $\mathrm{s}_{3}$ and $\mathrm{k}_{4}$, with $\mathrm{t}_{0}$ being the initial time interval necessary for the process to start. These processes could be associated with the oxygen reduction (Equation 2) from the material's surface and bulk, respectively. The regression plots showed a very good fit with the experimental data (Figure 8) and the corresponding coefficients are listed in Table 2.

The regression curve for $\mathrm{MgLi}_{0.1} \mathrm{Cr}_{1.9} \mathrm{O}_{4}$ suggests that the required time for the samples to achieve equilibrium is 40 hours and the decrease in conductivity in the interval $16-40$ hours is significantly less than the time interval $0-16$ hours. The time constants in Table 2 suggest that one of the processes is faster and one slower $\left(\mathrm{k}_{2}>\mathrm{k}_{4}\right)$ and they have similar contribution to the conductivity decrease $\left(s_{1}\right.$ and $s_{3}$, the same order of magnitude). 
The equilibration time for $\mathrm{MgCu}_{0.1} \mathrm{Cr}_{1.9} \mathrm{O}_{4-\delta}$ resulted to be $\sim 45$ hours. The time constants suggest that one of the processes is faster and one is slower $\left(k_{2}>k_{4}\right)$ and they have similar contribution to the conductivity decrease $\left(s_{1}\right.$ and $s_{3}$, have the same order of magnitude). $\mathrm{MgFe}_{0.1} \mathrm{Cr}_{1.9} \mathrm{O}_{4}$ reached equilibrium after $\sim 15$ hours and the time constants suggested one fast and one slow process $\left(\mathrm{k}_{2}>\mathrm{k}_{4}\right)$ and also that the first has the higher contribution to the conductivity decrease $\left(s_{1}>s_{3}\right)$.

Considering the samples that showed n-type behaviour, i.e. conductivity increased on reduction. $\mathrm{MgFe}_{0.5} \mathrm{Cr}_{1.5} \mathrm{O}_{4-\delta}$ reached its equilibrium conductivity upon reduction after 10.5 hours. $\mathrm{MgFeCrO}_{4-\delta}$ showed a similar behaviour, with the conductivity reaching a plateau after $\sim 10$ hours of reduction. The time constants showed one fast and one slow process $\left(k_{2}>k_{4}\right)$ with both processes having similar contribution to the increase in conductivity $\left(\mathrm{s}_{1} \approx \mathrm{s}_{3}\right)$. After the initial phase of decrease in conductivity, $\mathrm{Mg}_{1.5} \mathrm{Ti}_{0.5} \mathrm{CrO}_{4-\delta}$ reached equilibrium conductivity after $\sim 35$ hours of reduction, for which the time constants $\mathrm{k}_{2}=\mathrm{k}_{4}$ and the rate constants $\mathrm{s}_{1}=\mathrm{s}_{3}$.

The fast reduction kinetics observed for $\mathrm{MgFe}_{\mathrm{x}} \mathrm{Cr}_{2-\mathrm{x}} \mathrm{O}_{4}$ spinels could be related to a $\mathrm{Fe}$ enrichment of the material's surface, as also reported by Sakai et al. ${ }^{41}$ for $\mathrm{MnFeCrO}_{4}$. Sakai et al. ${ }^{41}$ found that $\mathrm{MnFeCrO}_{4}$ showed a surface enriched in $\mathrm{Fe}$, which also affects the oxygen transport properties. They concluded that fast oxygen isotope transport occurred in the $\mathrm{Fe}$ rich regions for $\mathrm{MnFeCrO}_{4}$, in comparison with the measured oxygen isotope transport for $\mathrm{MnCr}_{2} \mathrm{O}_{4}$.

Table 2 Fitting parameters for the variation of $\log (\sigma)$ with reduction time presented in Figure 8.

\begin{tabular}{|c|c|c|c|c|c|c|}
\hline \multirow{2}{*}{ Composition } & \multirow{2}{*}{$\mathrm{t}_{0}(\mathrm{~s})$} & & \multicolumn{2}{|c|}{ Initial process $(0-5 \mathrm{~h})$} & \multicolumn{2}{c|}{ Second process } \\
\cline { 3 - 7 } & & $\mathrm{k}_{0}\left(\mathrm{~S} \mathrm{~cm}^{-1}\right)$ & $\mathrm{s}_{1}\left(\mathrm{~S} \mathrm{~cm}^{-1}\right)$ & $\mathrm{k}_{2}\left(\mathrm{~s}^{-1}\right)$ & $\mathrm{s}_{3}\left(\mathrm{~S} \mathrm{~cm}^{-1}\right)$ & $\mathrm{k}_{4}\left(\mathrm{~s}^{-1}\right)$ \\
\hline $\mathrm{MgLi}_{0.1} \mathrm{Cr}_{1.9} \mathrm{O}_{4}$ & 1181 & 0.03961 & 0.13537 & $1.4895 \mathrm{E}^{-4}$ & 0.24854 & $3.4943 \mathrm{E}^{-5}$ \\
\hline $\mathrm{MgCu}_{0.1} \mathrm{Cr}_{1.9} \mathrm{O}_{4}$ & 2806 & 0.00496 & 0.07708 & $3.7942 \mathrm{E}^{-4}$ & 0.0364 & $6.9124 \mathrm{E}^{-5}$ \\
\hline $\mathrm{MgFe}_{0.1} \mathrm{Cr}_{1.9} \mathrm{O}_{4}$ & 2426 & $1.8004 \mathrm{E}^{-4}$ & 0.01767 & $3.1095 \mathrm{E}^{-4}$ & $8.1285 \mathrm{E}^{-4}$ & $4.9786 \mathrm{E}^{-5}$ \\
\hline $\mathrm{MgFe}_{0.5} \mathrm{Cr}_{1.5} \mathrm{O}_{4}$ & 331 & 0.00518 & -0.001 & $1.06 \mathrm{E}^{-3}$ & $-2.47 \mathrm{E}^{-3}$ & $1.0191 \mathrm{E}^{-4}$ \\
\hline $\mathrm{MgFeCrO}_{4}$ & 0 & 0.4042 & -0.16678 & $3.4366 \mathrm{E}^{-4}$ & -0.23465 & $4.9818 \mathrm{E}^{-5}$ \\
\hline $\mathrm{Mg}_{1.5} \mathrm{Ti}_{0.5} \mathrm{CrO}_{4}$ & 3874 & $2.8931 \mathrm{E}^{-4}$ & $-1.08064 \mathrm{E}^{-4}$ & $4.4669 \mathrm{E}^{-5}$ & - & - \\
\hline
\end{tabular}
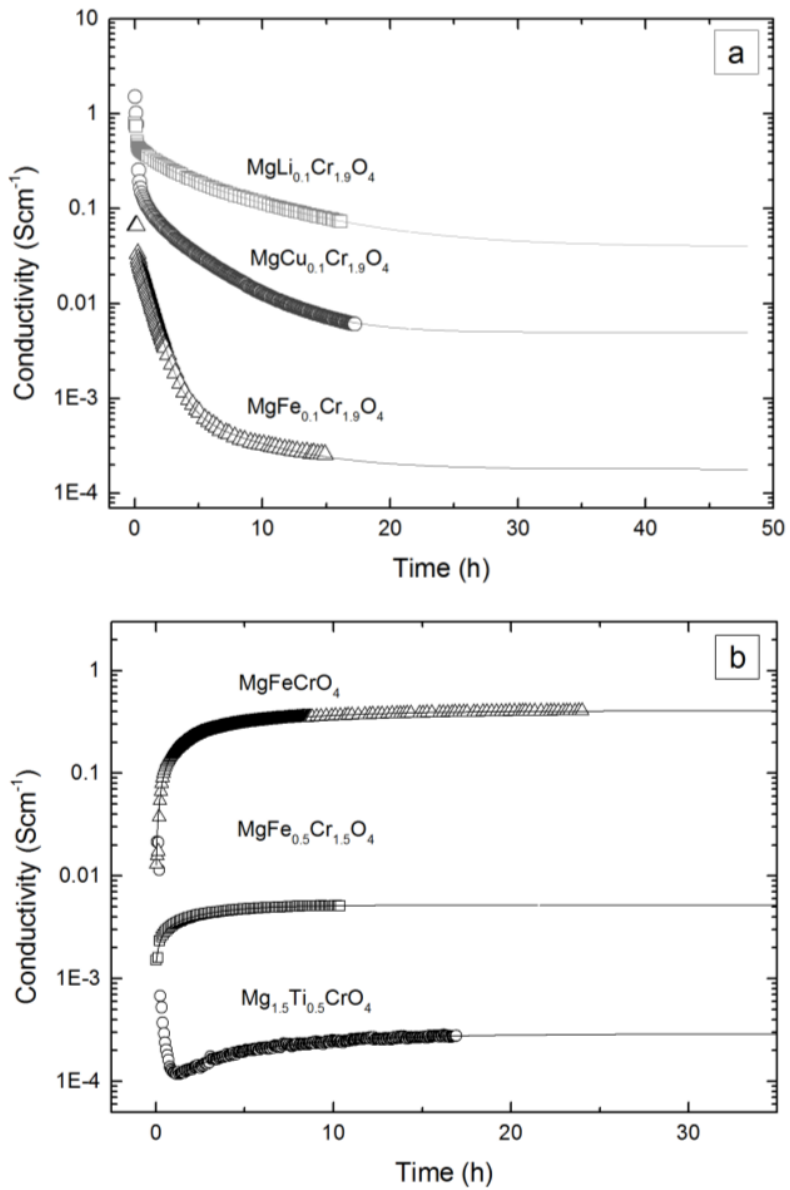

Figure 8 Variation of $\log (\sigma)$ and $\log \left(p \mathrm{O}_{2}\right)$ with reduction time the fitting of the datasets for longer reduction time at $850^{\circ} \mathrm{C}$.

\section{Conclusions}

The properties of $\mathrm{MgM}_{\mathrm{x}} \mathrm{Cr}_{2-\mathrm{x}} \mathrm{O}_{4},(\mathrm{M}=\mathrm{Li}, \mathrm{Mg}, \mathrm{Ti}, \mathrm{Fe}, \mathrm{Cu}, \mathrm{Ga})$ ceramics have been investigated to determine their suitability as potential electrode support materials in SOFCs. The materials have been found to form pure phase cubic spinels. Cations such as $\mathrm{Li}, \mathrm{Cu}$ and $\mathrm{Ti}$ showed a limit of solubility $(\mathrm{x} \leq 0.1)$ in the $\mathrm{MgM}_{\mathrm{x}} \mathrm{Cr}_{2-\mathrm{x}} \mathrm{O}_{4}$ spinel. A degree of inversion, $\gamma$ was estimated by means of Rietveld refinement of the X-ray diffraction patterns. The samples have been shown to be chemically stable in reducing conditions and only the $\mathrm{Fe}$ containing samples had limited stability under too harsh reducing conditions. $\mathrm{MgM}_{\mathrm{x}} \mathrm{Cr}_{2-\mathrm{x}} \mathrm{O}_{4}$ are p-type semiconductors for $\mathrm{M}=\mathrm{Li}, \mathrm{Mg}, \mathrm{Cu}, \mathrm{Ga}$ when measured in air or reduced. $\mathrm{Fe}$ substitution at the $\mathrm{B}$ site induced changes in the conduction mechanism of chromium spinels with positive effects for the conductivity in reducing conditions of $\mathrm{MgFeCrO}_{4}$, which had n-type conductivity due to partial reduction of $\mathrm{Fe}^{3+}$ cations to $\mathrm{Fe}^{2+}$. Too harsh reduction conditions $\left(>850{ }^{\circ} \mathrm{C}\right)$ reduced the $\mathrm{Fe}$ to metal. Also $\mathrm{Mg}_{1.5} \mathrm{Ti}_{0.5} \mathrm{CrO}_{4}$ had n-type conductivity in reducing conditions. $\mathrm{MgFe}_{\mathrm{x}} \mathrm{Cr}_{2-\mathrm{x}} \mathrm{O}_{4}$ spinels showed faster kinetics upon reduction, since the materials had a rapid response in conductivity variation with switching the atmosphere, in comparison with $\mathrm{Li}, \mathrm{Cu}$ or $\mathrm{Ti}$ substituted spinels.

The charge compensation corresponding to the substitutions at $\mathrm{B}$ site with $\mathrm{Li}^{+}$and $\mathrm{Cu}^{2+}$ implied an increase of charge on $\mathrm{Cr}^{3+}$ cations, as observed by the increase of the conductivity for $\mathrm{MgCu}_{0.1} \mathrm{Cr}_{1.9} \mathrm{O}_{4}, \mathrm{MgLi}_{0.1} \mathrm{Cr}_{1.9} \mathrm{O}_{4}$ and $\mathrm{MnLi}_{0.1} \mathrm{Cr}_{1.9} \mathrm{O}_{4}$ both in air and reducing conditions. The change in $\mathrm{E}_{\mathrm{a}}$ with the temperature range for $\mathrm{MgM}_{\mathrm{x}} \mathrm{Cr}_{2-\mathrm{x}} \mathrm{O}_{4}$ and $\mathrm{MnM}_{\mathrm{x}} \mathrm{Cr}_{2-\mathrm{x}} \mathrm{O}_{4}$ measured in air showed opposite tendencies: $\mathrm{E}_{\mathrm{a}}$ decreased with increasing temperature for $\mathrm{MgM}_{\mathrm{x}} \mathrm{Cr}_{2-\mathrm{x}} \mathrm{O}_{4}$, which is characteristic to a ceramic going from grain boundary to bulk domination of the conduction. For $\mathrm{MnM}_{\mathrm{x}} \mathrm{Cr}_{2-\mathrm{x}} \mathrm{O}_{4}$ an increase in activation energy would relate to the nature of the conducting species, maybe increase in number of carriers e.g. through reduction or 
breakdown of some ordering phenomenon that is limiting conduction.

The cation inversion observed in the Rietveld refinement for $\mathrm{MgFe}_{\mathrm{x}} \mathrm{Cr}_{2-\mathrm{x}} \mathrm{O}_{4}$ was supported by the material's electrical properties: the conductivity measured in air decreased and the activation energy values increased drastically with the increase of $\mathrm{Fe}$ content.

Overall, the spinels which showed good chemical stability, with no secondary phase segregation, maintained the p-type conductivity in reducing conditions. $\mathrm{MgGa}_{\mathrm{x}} \mathrm{Cr}_{2-\mathrm{x}} \mathrm{O}_{4}$ showed an electrical conductivity lower than the conductivity of the parent material, $\mathrm{MgCr}_{2} \mathrm{O}_{4}$, with a major decrease down to $10^{-5} \mathrm{~S} \mathrm{~cm}^{-1}$ which is a disadvantage for its application as electrode support materials. Even though $\mathrm{MgCu}_{0.1} \mathrm{Cr}_{1.9} \mathrm{O}_{4}, \mathrm{MgLi}_{0.1} \mathrm{Cr}_{1.9} \mathrm{O}_{4}$, maintained higher conductivity when reduced, the improvement in conductivity was not sufficient. $\mathrm{MgFeCrO}_{4}$ may be a good compromise between conductivity and chemical stability for the anode support application.

\section{Acknowledgements}

The authors thank the Office of Naval Research, USA, grant code N00014-11-1-0247, the Engineering and Physical Sciences Research Council, UK, grant platform EP/E064248/1 and the European Union's Seventh Framework Programme (FP7/2007-2013) for the Fuel Cell and Hydrogen Joint Technology initiative under grant agreement $\mathrm{n}^{\circ}[\mathrm{FCH}$ JU-GA 278257]10 for financial support.

All authors have given approval to the final version of the manuscript.

\section{Notes and references}

${ }^{a}$ School of Chemistry, University of St. Andrews, Fife KY16 9ST, U.K.

*E-mail: jtsi@st-andrews.ac.uk.

* Current address: Faculty of Integrated Technologies, University Brunei Darussalam, Gadong BE 1410, Brunei Darussalam.

1. A. Galich and L. Marz, Energy Sustain. Soc., 2012, 2, 2.

2. D. Neagu and J. T. S. Irvine, Chem. Mater. ACS Publ., 2010, 22, 5042-5053.

3. R. Knibbe, H.-J. Wang, P. Blennow, K. Thydén, Å. H. Persson, L. Mikkelsen, and T. Klemens $\varnothing$, J. Power Sources, 2013, 228, 75-82.

4. J. Goodenough and Y. H. Huang, J. Power Sources, 2007, 173, 1-10.

5. E. Povoden-Karadeniz, Thermodynamic database of the La-Sr-Mn$\mathrm{Cr}$-O oxide system and applications to solid oxide fuel cells, [s.n.], [S.1.], 2008.

6. J. C. Ruiz-Morales, J. Canales-Vázquez, B. Ballesteros-Pérez, J. Peña-Martínez, D. Marrero-López, J. T. S. Irvine, and P. Núñez, J. Eur. Ceram. Soc., 2007, 27, 4223 - 4227.

7. S. M. Plint, P. A. Connor, S. Tao, and J. T. S. Irvine, Solid State Ion., 177, 2005-2008.

8. J. T. S. Irvine and P. Connor, in Solid Oxide Fuels Cells: Facts and Figures, eds. J. T. S. Irvine and P. Connor, Springer London, 2013, pp. 163-180.

9. M. Gross, J. Vohs, and R. Gorte, J. Electrochem. Soc., 2007, 154, B694-B699.

10. W. Z. Zhu and S. C. Deevi, Mater. Sci. Eng. A, 2003, 362, 228 - 239.

11. S. McIntosh, J. M. Vohs, and R. J. Gorte, Electrochimica Acta, 2002, 47, 3815-3821.
12. H.-S. Noh, J.-W. Son, H. Lee, H.-I. Ji, J.-H. Lee, and H.-W. Lee, J. Eur. Ceram. Soc., 2010, 30, 3415-3423.

13. S. Choi, J. Wang, Z. Cheng, and M. Liu, J. Electrochem. Soc., 2008, 155, B449-B454.

14. J. Rossmeisl and W. G. Bessler, Solid State Ion., 2008, 178, 1694 1700 .

15. J.-S. Kim, V. V. Nair, J. M. Vohs, and R. J. Gorte, Scr. Mater., 2011, 65, 90-95.

16. X. Yang and J. T. S. Irvine, J Mater Chem, 2008, 18, 2349-2354.

17. Y. Huang, J. M. Vohs, and R. J. Gorte, J. Electrochem. Soc., 2004, 151, A646.

18. W. Wang, M. Gross, J. Vohs, and R. Gorte, J. Electrochem. Soc., 2007, 154, 8439-8445.

19. Corre, G. Kim, M. Cassidy, J. M. Vohs, R. J. Gorte, and J. T. S. Irvine, Chem. Mater., 2009, 21, 1077-1084.

20. J. H. Kim, D. Miller, H. Schlegl, D. McGrouther, and J. T. S. Irvine, Chem. Mater., 2011, 23, 3841-3847.

21. H. S. C. O’Neill and A. Navrotsky, Am. Mineral., 1983, 68, 181-194.

22. K. E. Sickafus, J. M. Wills, and N. W. Grimes, J. Am. Ceram. Soc., 2004, 82, 3279-3292.

23. E. W. Gorter, Saturation Magnetisation and Crystal Chemistry of Ferrimagnetic Oxides, Phillips, 1954.

24. A. R. West, Basic Solid State Chemistry, Wiley-Blackwell, 2nd Edition., 1999.

25. A. Putnis, Introduction to Mineral Sciences, Cambridge University Press, 1992.

26. C. E. Housecroft and A. G. Sharpe, Inorganic chemistry, Pearson, Harlow, England; New York, Fourth Edition., 2012.

27. D. Neagu, Thesis, University of St Andrews, 2013.

28. R. D. Shannon, Acta Crystallogr. A, 1976, A32, 751-767.

29. L. Morozova and V. Popov, Glass Phys. Chem., 2010, 36, 86-91.

30. D. M. Flot and J. T. S. Irvine, Solid State Ion., 2000, 135, 513518(6).

31. H. Moriwake, I. Tanaka, F. Oba, Y. Koyama, and H. Adachi, Phys. Rev. B, 2002, 65, 153103 .

32. H. Moriwake, S. Watanabe, and K. Ogasawara, Jpn. J. Appl. Phys., 2007, 46, 4175-4178.

33. H. Moriwake, I. Tanaka, F. Oba, Y. Koyama, and H. Adachi, Int. J. Quantum Chem., 2003, 91, 208-210.

34. E. Stefan and J. T. S. Irvine, J. Mater. Sci., 2011, 46, 7191-7197.

35. E. Stefan, P. A. Connor, and J. T. S. Irvine, J. Mater. Chem. A, 2013, 1,8262 .

36. E. Stefan, G. Tsekouras, and J. T. S. Irvine, Adv. Energy Mater., 2013, n/a-n/a.

37. J. Rodríguez-Carvajal, Comm. Powder Diffr. IUCr, 2001, Newsletter 26, 12-19.

38. P. Kovtunenko, Glass Ceram., 1997, 54, 143-148.

39. T. Suzuki, K. Adachi, and T. Katsufuji, J. Magn. Magn. Mater., 2007, 310, 780-781.

40. T. D. McColm and J. T. S. Irvine, Ionics, 2001, 7, 116-121.

41. Sakai, T. Horita, Y. P. Xiong, K. Yamaji, H. Kishimoto, M. E. Brito, H. Yokokawa, and T. Maruyama, Solid State Ion., 2005, 176, 681686. 